\title{
Empowerment: A Theological Perspective'
}

C R Dickson

\section{AIBSTRACT}

Empowerment: a theological perspective

It is generally accepted that sound practice must be informed by sound theory. This maxim applies also with reference to the concept empowerment which is in vogue within South Africa today. Therefore it is angued here that for empowerment to be effective it must be underpinned by a sound theological understanding of powerlessness. After exploring the use of the term power (powerlessness), its occurrence and meaning in Psalm 82 is examined, concluding with an attempt at formulating a theological definition of powerlessness. This is followed by a survey of the concept powerlessness as it is found in current literature. These understandings of powerlessness are also evaluated. Finally the benefits of a theologically defined concept of powerlessness as basis for empowerment are discussed.

\section{INTRODUCTION}

As we move to a new dispensation in South Africa, a term which has gained great currency is the word empowerment. Every vision for South Africa in one way or another focuses on this issue. At the World Trade Centre in Kempton Park different aspects of this issue received attention. The constitutional negotiations seek to empower; affirmative action is targeted at empowering the previously powerless; economic and educational restructuring has the same aim in mind.

But it is maintained here that for empowerment to be effective it must be underpinned by a sound theological understanding of powerlessness (poverty). This is important because of the inseparable link between one's concept of powerlessness and the strategies designed to empower the powerless. It must be noted that an inadequate concept of powerlessness can lead to an ineffective empowering strategy. Therefore, it is argued here that a theologically defined concept of powerlessness is vital for effective strategies of empowerment.

\section{A THE CONCEPT OF POWER AND POWERLESSNESS}

Morris $^{2}$ makes it clear that power, and by implication powerlessness, can be used in three basic ways: 
Power in this sense is the power to get things done, or to change things. This understanding of power is dominated by an ability concept of power. It must be noted that the exercise or non-exercise is not an issue in this understanding of power, for passive (non-exercised) power can be more powerful than active power. This distinction intends to stress the fact that power is not just about ability but also about the actuality of getting things done.

Power used to attribute responsibility and blame

Accountability is expected and blame and praise attributed on the premise that the person has the power to do what is expected, desired or required. As Morris ${ }^{3}$ says: "to have power or responsibility is to be able to do things". Operative here is the principle which says "ought implies can"4. If a person does not have the power to do or not to do a thing, he cannot be held accountable; he cannot be blamed or praised, since the outcome has nothing to do with his power to do or not to do. With this use power is also understood as an ability concept.

Power used to evaluate social systems

In this context power is used as a means of evaluating the distribution of power within a society or social system, "for people can, and do, value one distribution of power more than another"5. It is used to express a judgement on the way power is distributed between $A$ and $B$ in a society. It seeks to determine whether $A$ has more power than B. Thus power functions to evaluate how abilities are distributed in a society, for societies can be judged "by the extent to which they give their citizens freedon from the power of others [influence concept] or by the extent to which citizens have the power to meet their own needs or wants [ability concept]"6. According to Gowan, the Old Testament material on wealth and poverty should be used in this evaluative sense. This is clear from his remark: "the Old Testament material has enduring value for descriptive purposes. The Old Testament's final criterion was diagnostic, and it can still be used that way"7.

\section{B THE CONCEPT OF POWERLESSNESS IN PSALM $82^{8}$}

When we turn to Psalm 82, which of these understandings of powerlessness do we find there? The Psalm views the poor as powerless in the sense that they are unable to get the things they want, done. They lack the ability to get things done. It was 
mentioned above that powerlessness in an evaluative sense can be understood both as an ability or influence concept or rather as an ability concept qualified by an influence nuance. We find this use of powerlessness in Psalm 82 as well. On closer examination, however, it appears that powerlessness in Psalm 82 refers not so much to the fact that the poor are under the control of others, but to their lack of ability; they are powerless. We see this in the way God speaks to the gods. He commands them:

$\begin{array}{lll}\text { 1. } & \text { Verse 3a: } & \text { give justice } \\ \text { 2. } & \text { Verse 3b: } & \text { maintain the right } \\ \text { 3. } & \text { Verse 4a: } & \text { rescue the weak } \\ \text { 4. } & \text { Verse 4b: } & \text { deliver them from the hand of the wicked. }\end{array}$

This command to empower the poor through deliverance from the power of the wicked will be accomplished to the extent that the gods heed God's call to maintain justice in the cosmos. Thus verse 3 is God's call to the gods to empower and enable the powerless and in this way break the influence of the powerful.

Prinsloo maintains that verses 3-4 "are built up in a parallel manner"'), and are therefore also similar in meaning. On this basis we can infer that the imperatives in verse 3-4 have the emphasis of enabling the powerless. God calls upon the gods to empower the powerless; to restore to them the ability to obtain the justice they desire, deserve and require. For the issue in poverty is not that the poor have abilities which they are not using. Rather it is the fact that the poor lack ability; they are unable to obtain what they desire, deserve and require. To use the words of Morris who says: "to be impotent (powerless) is to lack an ability"10.

The evaluative use of powerlessness is evident from the consequences of the misrule of the gods contained in the climatic description of verses 5-6: "all the foundations of the earth are shaken". The cause of the chaotic state of the society (cosmos) is diagnosed as the inability of the poor to obtain what they need and desire. Their powerlessness is the basis for God's evaluation of the society as chaotic. Psalm 82, therefore uses the concept powerlessness as an evaluative term.

But Psalm 82 goes further than just recognising the importance of the ability aspect of the concept powerlessness. It also focuses on the empowering of the powerless. It sees the enablement and empowerment of the powerless as coming from God. The inability (powerlessness) of the powerless are dealt with as they turn to God, the source of their empowerment. It is in looking to God, hoping in God, trusting in God, waiting upon God, depending upon God, that the powerless find their empowerment. Thus Psalm 82 adds another dimension to the concept powerlessness, that of abject, total dependence upon God. So powerlessness 
theologically defined is: the abject, total dependence upon God by the powerless in the quest to be empowered and enabled. In the context of the above powerlessness means to abandon oneself to another person; that is to God. Kvalbein writes in this regard that powerlessness refers to "the fundamental position of man before God as helpless, as sinner, regardless of the material resources or social position"11. Mcpolin describes the poor as "those who place their total dependence upon God, who plead helplessness before God. They are not delivered by their own power but by the power of God. In this sense they would be spiritually poor"12. The last sentence of McPolin could be rephrased more appropriately: in this sense they are powerful.

\section{CONCEPTS OF POWERLESSNESS IN CURRENT LITERATURE}

Poverty is being understood increasingly as powerlessness. A number of articles and books have been written on poverty from this perspective. But what concept of powerlessness do we encounter in this literature? How does this concept of powerlessness relate to the insight developed in Psalm 82? The answer to these questions will be our next concern. A number of recent publications which consider poverty from the perspective of powerlessness are now discussed and evaluated.

1 Concepts consistent with the understanding of powerlessness in Psalm 82

1.1 R W Lyon ${ }^{13}$ writes from a concern for evangelicals and particularly their ineffectiveness to impact the world scene and modern society. His analysis of North American evangelicalism shows that it is ineffective because it relies on the same sources and forms of power society rely on, that is: success, wealth, politics; economic, social and military power. Against this background Lyon calls for a new brand of evangelicalism characterised by: (a) the renouncement of "power"; (b) a commitment to powerlessness in terms of life-style. Powerlessness is now defined by Lyon as being "dependent upon the word and Spirit". It means "to abandon ourselves to them" (i e word and Spirit). Therefore Lyon sees powerlessness as "abject dependence" upon God, his Word, and his Spirit. This formulation of powerlessness is consistent with the theologically defined concept of powerlessness referred to above.

Mott's ${ }^{14}$ criticism that Lyon does not define powerlessness is not valid, for implicit in Lyon's definitions of powerlessness is his understanding of power. This understanding of power uses power to evaluate society or a sector within a society. What can be said against Lyon, though, is that he does not draw out the implications of his understanding of powerlessness for the socio-political and structural obstacles 
in the fabric of the society clearly enough. An inadequate attempt is made at this ${ }^{15}$. In the end Lyon ends up where Shourie (see below) finds himself.

\subsection{J Moltmann 16}

Moltmann's book is a collection of sermons. The concept powerlessness gives the sermons coherence. Each sermon in one way or another deals with this theme. He understands powerlessness in the sense of the limitations people experience in their daily lives ${ }^{17}$. The limitations are experienced perpetually. The Bible is then used to see how others who have experienced similar limitations in the past, coped with them. Scripture is seen to provide models for dealing with the limitations experienced in daily life. Moltmann perceives the problem not as the limitation (powerlessness) itself, but the manner in which it is being met with by the individual. Consequently, for Moltmann powerlessness is part of the human condition, since it is part of the everyday existence and life of ordinary people. By looking at the Biblical material and the way in which those in the Bible have dealt with their limitations, Moltmann wants to answer the questions: Where did these people get their power from? How did the powerless live meaningfully in the face of their powerlessness? His answer: From the Spirit, from God. Powerlessness is therefore conceived of by Moltmann as that which is imposed upon our being; impositions upon our humanity. Thus powerlessness is conceived negatively. It is that which restricts the being from being what it potentially can be and ought to be.

From this discussion it is clear that Moltmann has a theological concept of powerlessness, namely, total dependence upon God and his Spirit; and this understanding is best suited to an ability concept of power and powerlessness. Moltmann works with an ability concept of power and powerlessness, theologically defined, which is necessary if strategies which seek to address the real powerlessness of the powerless are to be formulated.

\subsection{L Miglor 18}

"Power is the ability to do something. It is the capacity to accomplish a purpose"19. Power can be experienced actively (I do, act), or passively (I am acted upon, limited) by the power of others. Therefore power can, in a sense be said to be experiencing of the power of others in a negative way. Given this understanding of power and powerlessness, poverty as powerlessness can be described as experiencing the negative use of economic power by others. Sociologically and politically power is "the ability of one group or class or nation to have its way and to control others" 20 . It is clear from this discussion that Miglor works with an ability concept of power 
and powerlessness. The weakness of Miglor's treatment is that he does not spell out the implications for empowerment in terms of the socio-political and economic realities of society.

2 Concepts inconsistent with the understanding of powerlessness in Psalm 82

2.1 C Shourie 21 maintains that governments and their agencies together with those involved in development work have failed to deal effectively with poverty. Evidence for this is seen in the fact that government programmes make little difference to the poverty of the poor. In addition the failure by development agencies to actualise their convictions is further proof of this. The fundamental reason for this state of affairs is that governments and agencies have diagnosed the problem of poverty incorrectly. Both have defined poverty in terms of its fruit rather than its root. Shourie expresses the root of the problem as follows: "Poverty is powerlessness"22. But what is powerlessness? To arrive at an answer Shourie first defines power as follows: "Power is the ability to control various factors in order to perpetuate selfish gain over and above the legitimate interests of others"23. Power is: to have control over. Given this, powerlessness is defined by Shourie as not exercising control over, particularly over oneself and one's resources as well as not resisting the control of others over oneself.

It is clear that Shourie works with an influence concept of power and powerlessness. He, moreover, sees the problem in terms of influence over the mind of the poor. He remarks, for example, that the poor should be made to "challenge from heart and mind" 24 the existing order of things. Further, that the poor are poor because they do not "have the resources they think they need"25. For him powerlessness is a state of mind. Shourie says as much by virtue of the constant reference to "believe", e g "with such beliefs; they believe in the same sources of power; and the poor are equally responsible for their very acceptance of these beliefs brought them, in the first place into existence"26. Poverty, according to Shourie is therefore a problem of consciousness; of a wrong mindset, of a wrong state of mind. How are the poor to be empowered? By "generating faith and confidence among the poor: faith in the values inherent in the New Order, confidence to choose it [ $i$ e these values]"27. Consequently, poverty is dealt with when we are able to get the poor to change their minds; to get them to believe something different. And what is that something different? It is the values of the New Order, the values of the Kingdom of God.

Shourie is correct to point out that unless poverty is seen as powerlessness, the root problem(s) of poverty will not be addressed. But Shourie himself fails to 
address the root problem of poverty because he works with an inadequate concept of powerlessness which inevitably leads to an inadequate strategy for dealing with the problem of poverty. He no doubt identifies the real problem. The weakness is his solution which does not go far enough to address the problem. According to Shourie the solution is in a "totally different source of power: the power which Jesus proclaimed" and which has "God as its definition. As people turn to God, the power of God is made available to them", and having this power, "they begin to resist the control of others over their lives and resources"; and they resist "not by a coup or a massacre" but by choosing biblical values such as "service, mutual dependence, selfcontrol, mutual love, respect, trust, harmony and reliability; in other words realise the intrinsic worth of created man"28.

So then: the way for the poor to remove the control of others over them is for the poor to turn to the New Order and power available through participating in this New Order which is the Kingdom of God. Spiritual conversion is the strategy Shourie uses to deal with the root problem of powerlessness. Thus Shourie's answer lies on the spiritual, personal and individual planes only. Why? because he works with a concept of powerlessness which is not sufficiently informed theologically.

There are real structural obstacles in the fabric of the society which contributes to the powerlessness of the powerless. And to focus on this, an influence concept of powerlessness is inadequate. What is needed is a theologically defined ability concept of powerlessness as described above. Shourie's person who does not follow the power dynamics of this world, but follows the values of the Kingdom of God, will still be unable to obtain a fair share of what can be described as the common social good due to the structural hindrances in the society, as Psalm 82 makes abundantly plain. His starting point is that human nature is essentially selfish. This selfishness expresses itself in the desire to gain more. How is this gain obtained? Through control over others. The solution is therefore to change human nature from it's selfish orientation towards another orientation which aims "to direct [one's resources] in a way which builds himself and others" 29 . How is this new orientation achieved? By spiritual conversation. Therefore, a new nature is the solution to the root problem of poverty.

Once again we have an answer to poverty which leaves it on the spiritual level, and ignores the socio-political and the eco-socio-structural levels of the problem. Shourie himself points to and identifies certain structural problems but fails to address these. He rightly points out that "a mere reshuffling of resources does not solve anything at all, creating rather only a new population of the poor" 30 . It is not just the transference of power to those who do not have power. It involves "the transference of allegiance to a greater Power"31. But this is merely to acknowledge that a strategy for empowerment must have a sound moral and spiri- 
tual base; and this is very important. But his solution remains inadequate for addressing the root problem of poverty which is powerlessness.

2.2 H R Weber ${ }^{32}$ points out that power manifests itself at different levels: social, military, political, economic, natural forces (like wind, water, fire); authority (of men and women); the divine and demonic (behind the scenes in nature and history). Power takes on all these forms. Understanding power biblically means being able to see the interaction between God's power and these powers as God struggles to establish his kingdom on earth. Powerlessness is availability to God to be used by Him as His instruments in the establishment of his kingdom on earth. It is therefore seen in terms of agency and instrumentality. Powerlessness is participation in the struggle of God to establish his kingdom on earth.

Weber works with a concept of power which is essentially conflictive. Foundational to a conflictive concept of powerlessness is the definition of power as power over. The solution in such a situation is to overthrow the controlling power and in this way remove the powerlessness of the powerless including the use of revolutionary methods. Consequently the active revolutionary struggle of the powerless is God struggling to set up his kingdom; making his power felt in the world. The question which remains, however, is: What happens after the revolution? Recent history seems to show that the powerless continue to be powerless. The inabilities of the poor remain even after the struggle and the revolutionary overthrow of those who exercise power over. There is a transfer of power which does not necessarily lead to the effective empowerment of the powerless. A conflictive concept of powerlessness, based as it is on the influence concept of power, is inadequate. It is necessary to conceive of powerlessness as a theologically defined ability concept for empowering to find expression in the real empowerment of the powerless. In this way the causes and not merely the symptoms of powerlessness will be addressed.

2.3 S Mott ${ }^{33}$ accepts Max Weber's definition of power which is functional. It contends that some hold power at the expense of others and use that power to further their own interests. Moreover, he maintains that powerlessness means "being controlled by others for their gain" or the "denial of aspects of participation in the community". Against this background "powerlessness" means the lack of, the absence of a sufficient amount of the constant-sum of power in the society resulting in the inability to realize one's will or the inability of a group of people to realize their will. "Power is an aspect of social relations. It is not being held in isolation from others but in relation to others." Consequently, for Mott "power is power over others". 
Jesus' ministry is now evaluated in terms of this concept of power over (influence concept). So Mott argues: (a) power is not at stake in the temptation; (b) Jesus was not powerless; (c) the power demonstrations by Jesus, (miracles, temple cleansing, etcetera which are political power demonstrations) resulted in his death. Power, not powerlessness caused Jesus' death. But what are we to make of Jesus' own admission of his own powerlessness? He did not know the hour of his second advent? I think an influence concept is not adequate to deal with the issue of power in the life of Jesus.

The remark by Mott that: "humility and trust do not equal powerlessness" cannot stand the test of biblical material. The Psalms in particular shows this in fact to be the case. Mott's remark that: "Jesus did not substitute this power for dependence upon God, but in his career he indeed did exercise that power for others", drives a false dichotomy between power and dependence upon God, a dichotomy not evident in Scripture, as the Psalms bear testimony. Put another way: the fact that he used power for others instead of in his own interest does not mean less reliance upon God. Mott sees "powerlessness" as abdicating divinely given responsibilities. But this is only true on the basis of his definition of power. If power is the use of power for selfish ends (as Mott would have it) then powerlessness is abdication.

\section{$2.4 \quad$ D E Gowan}

Gowan ${ }^{34}$ deals primarily with the Old Testament teaching on wealth and poverty. He focuses on wealth because he believes that research on poverty has neglected the aspect of wealth. He concludes that the Old Testament's teaching on poverty and wealth cannot be accepted as prescriptive but rather as diagnostic, $i$ e it does not give specifics on how we should deal with wealth and poverty. It rather helps us to determine the state of a society. To address the issue of wealth and poverty Gowan looks at the Old Testament's teaching on the poor, widow, orphan and stranger. He sees them as examples of "powerlessness". In other words the common denominator characteristic of these concepts is the idea of powerlessness. The four categories of poor, widow, orphan, and stranger can be used to diagnose whether a society is healthy or not. The extent to which a society is characterised by the biblical demands of mishpat, hesed, and rahamin is indicative of the health or illhealth of that society. These values or norms find concrete expression in the status of the powerless (poor, widow, stranger and the orphan) in the society. But what does Gowan understand by powerlessness? He conceives of powerlessness as the "inability to maintain rights"35. In addition to the "ability" concept, Gowan defines 
powerlessness as "not enough power"36. But this description of powerlessness leads us back to Max Weber's constant-sum (zero-sum) concept of power.

Moreover, it is a good example of using a power concept as if it is an ability concept. The mere use of the word ability in a description of power does not mean a genuine ability concept of power is being employed.

The weakness of Gowan's position is his contention that the Old Testament does not give prescriptions on the issue of poverty and wealth. But Psalm 82:3-4 indeed gives such prescriptions for dealing with powerlessness. It may not give a detailed blue print but does tell us that justice must be done; that a certain state of affairs must exist in society. It is certainly more than diagnostic. It is prescriptive indeed.

\subsection{Carmichael and l lamilton}

They provide a political definition of power from a black perspective. Power is defined as "control over the minds of men"37. They write: "where black people have a majority, they will attempt to use power to exercise control. This is what they seek, namely, control. Where black people lack a majority, Black power means sharing control"38. This understanding of power is rooted in their conviction that for ages blacks have been controlled, their thinking, their living, and development; just about everything has been controlled. Therefore empowerment of the black person means wrestling control from and then exercising control over the black self. To accomplish this any means is legitimate.

Summarising: Powerlessness is to be under the control of others. Empowerment is the revolutionary overthrow of whatever and whoever exercises control over those who are powerless. The weaknesses inherent in the influence concept of power applies here as well. For example: Even though control by whites over blacks in South Africa is abolished by the democratic elections of April 1994, blacks will still face major areas of powerlessness. They will continue to lack ability in significant areas of their daily lives such as the economic, social, education and health spheres.

\section{GENERAL EVALUATION OF POWER CONCEPTS}

Characteristic of the theories of power discussed above is the fact that powerlessness is defined as the lack of control over. The influence concept dominates. That the specific strategy for empowerment proposed is a direct outflow of the particular understanding and definition of powerlessness employed will become clear from the discussion which follows. 
The definitions discussed make use of "class" theory which seem to lie at the base of the influence concept of power. Class theory depicts the poor and rich as social classes. The theory contends that in the Bible there is a "class" or "collective group" called the poor. De Vaux ${ }^{39}$ disputes that this is the case. The problem with the theory is its contention that the poor exist because the rich exist. But it would appear that the poor exist because the provisions regulating the relationships between people in society are disregarded. This is the reason for the presence of poor people in the society, as Psalm 82:3-4 makes very clear. Consequently poverty (powerlessness) cannot be resolved by simply transferring power. Something more must be added. That something extra is the presence of a moral and spiritual base. Put differently, values and norms must support the transfer of power. For this to happen we must therefore conceive of power in more than just political terms. Our understanding of power and powerlessness must be broadened to include spiritual, moral and religious elements. It is at this point that our analysis of Psalm 82 and our theological conception of powerlessness is of value.

Another weakness of the definitions discussed is the concept of human nature evident in the concepts of power and powerlessness. Power is discussed within the limits of sheer human possibilities. Human nature in the concepts of power discussed tends to be conceived of as determined by the context. Human nature is seen as autonomous and totally independent, having to work out it's own salvation. This is certainly a very narrow and unbiblical concept of human nature.

The constant-sum concept essential to the concepts of power and powerlessness discussed above, humanizes God excessively. He is pictured as being unable to stand "above" the struggle for power. In fact $\mathrm{He}$ is part and parcel of the struggle for power. The danger here is that He may be found to be affected by the outcome of this struggle for power; something like the gods of the nations around Israel who are defeated when the nation is defeated by Israel. In addition it is a conflict concept of power which inevitably creates a conflictive society in which the Biblical values of peace, justice, and righteousness is seldom evident.

These concepts allow no room for divine sovereignty. They lead to domination rather than to mutuality and interdependence. For example Steven Mott's criticism of Lyon breaks down because Mott fails to see that even power is a created datum. We really do not know the essence of power. Power, like time and life, is a created thing and cannot be seen as existing outside of God. Thus God is not power, he uses power. In other words to say of God that he is power or might is not an analytical and philosophical statement which describes the essence of God but a descriptive statement of power encounters of and with God, or descriptive statements expressing our observations of the power manifestations of God. 
Statements to the effect that God is power promote power for its own sake. Power then becomes an end in itself.

\section{BENEFITS OF THE THEOLOGICALLY DEFINED CONCEPT POWERLESSNESS}

According to Shourie ${ }^{40}$ the root problem of poverty will never be addressed until we see poverty as fundamentally powerlessness. And because governments and other agencies have not grasped this, their empowerment programmes have been ineffective. Against this background conceiving of poverty as powerlessness has the following benefits:

The diagnostic aspect helps us to target our empowerment programmes as the correct levels. Poverty and empowering programmes which does not address areas requiring real empowerment would be evaluated as not really helpful to the poor and powerless.

The evaluative function performed by the concept powerlessness helps with the assessment of programmes. It can be used to gauge the "success" of empowerment attempts way. When we do that which merely relieve poverty and stop, we are not addressing the core problems, since relief efforts imply that the poor have abilities which have temporarily been hindered. Once the temporary hindrance has been removed the poor will be in a position to use their suspended abilities. The concept of powerlessness implicit in relief programmes betrays an unbiblical understanding of the poor. The Old Testament and the Psalmist seem to indicate that the poor are really powerless and that any assistance must address this situation if it is to be meaningful.

It also evaluates empowering programmes according to whether they make a difference. Poverty programmes which are aimed at dealing merely with the apparent problems of the poor are equally ineffective. The experience of the Black American civil rights movement is a case in point. Even though black Americans were empowered legally and constitutionally, they continued to be powerless. The civil rights movement aimed at making the de jure situation the de facto. The same is true in the area of empowering the powerless. In this way the concept of powerlessness serves an evaluative function checking whether empowerment programmes are successful, $i$ e whether they have resulted in real empowerment for the poor and powerless.

Powerlessness theologically defined has another dimension: it gives to the problem of poverty a transcendent aspect. It calls on God to intervene and therefore provides hope instead of resignation. If there is another powerful source 
that can intervene and change things it gives meaning to the efforts and struggles in addressing real powerlessness.

In addition, the theologically defined concept of powerlessness brings to empowerment efforts a spiritual dimension. It opens up a perspective of the poverty and empowerment problem that can so easily be missed. It ensures that we in fact diagnose and target correctly the need for empowerment in that it opens up the spiritual in the human person. Put differently: all political and economic changes must be based on moral and spiritual values. Here one can think for example of the lost generation in Soweto made up of young people who are growing up without real spiritual, moral and religious values. If they are given socio-political and economic empowerment without a moral, religious and spiritual base, we might end up with a situation in which the might is right approach is resorted to in order to resolve the difficulties which are perceived to be the causes of poverty. Brute force becomes the method for dealing with the perceived causes of powerlessness in society. Understanding powerlessness theologically therefore underpins empowering strategies with a spiritual base.

Powerlessness understood theologically also challenges the comprehensiveness of our empowerment efforts. For underlying a theologically defined concept of powerlessness is a specific theory of human nature. It perceives man as a whole person with an integrated physical, mental, spiritual, emotional and moral dimension. Consequently empowerment strategies must seek to address the whole person. A theologically defined concept of powerlessness will ensure this.

Powerlessness theologically understood emphasises accountability which flow out of the concept of interdependence. Powerlessness says human persons are not autonomous but dependent beings. Our very creatureliness stresses this point. If human persons are not autonomous, then co-operation is required to achieve goals. So powerlessness calls for co-operation between the "haves" and the "havenots" in order that poverty is addressed meaningfully. This must be done in such a way that the accountability of both parties is evident for interdependence calls for mutual accountability. Both the implementers and beneficiaries of empowerment strategies are in the final analysis accountable to God.

Powerlessness understood in the way we have defined it ensures that our strategies for empowerment make room for the Biblical perspective of powerlessness as complete reliance upon God. The poor of Yahweh is so named, precisely because they are totally dependent upon him. Powerlessness as human dependence is a positive concept. This idea of powerlessness as positive dependence ensures that empowerment strategies and processes remain humane, just and righteous. Without this we may have a situation in which the previously oppressed become the oppressors; the under-dogs, top-dogs; yet dogs all the same. The concept of 
dependency upon Yahweh can save us from inhumanity; can save us from being instruments of the loss of human dignity which other people may experience.

Our concept of powerlessness has ethical implications, and can thus assist in dealing with the issue of revenge and bitterness. It can serve as the basis for reconciliation rather than retaliation. The qualities of humaneness, justice and righteousness discussed above are criteria by which empowerment strategies should be judged. For the goal of empowerment is not just the transfer of power but the establishment of justice (cf. Ps 82). The question to be asked of empowerment strategies is: do they contribute to the manifestation of justice, peace, righteousness, and reconciliation in society? But we can only expect empowerment strategies to conform to such criteria if the concept of powerlessness which informs the empowerment strategies take seriously the idea of dependence upon Yahweh put forward in this discussion. And it is also against this background that words like helpless, powerless, should be used. They express relationships, particularly the relationship between God and people.

\section{E CONCLUSION}

Powerlessness is a term often used in discussion on poverty. What we have attempted to do was to formulate a definition of powerlessness which takes its cue from Psalm 82. Against this background several concepts of powerlessness current in the literature on poverty were assessed.

It was found that a concept of powerlessness, defined theologically, is needed in order to deal with the real fundamental problem of powerlessness which is the inability of the poor to get things done.

To motivate this contention several advantages of a concept of powerlessness theologically defined were discussed.

The conclusion to be drawn from this exploration is that the concept powerlessness encountered in Psalm 82 is vital as a basis for empowerment strategies which attempt to address the real (de facto) problems of poverty and powerlessness. It is in this that the value of a concept of powerlessness theologically defined is to be found.

\section{NOTES:}

1 Part of the author's M A dissertation, Poverty as powerlessness: An exegetical study of the meaning of the Hebrew terminology for poor in Psalm 82. Department of Biblical Studies, University of Pretoria, 1993.

2 P Morris, "The essentially uncontestable concepts of power", in: The frontiers 
of political theory, (Edited by M Freeman \& D Robertson), Herts 1980, 198 232.

3 Morris, ibid, 207.

$4 \quad$ Morris, ibid, 213.

$5 \quad$ Morris, ibid, 207.

6 Morris, ibid, 208.

7 D E Gowan, "Wealth and poverty in the Old Testament": The case of the widow, the orphan and the sojourner, Interpretation 41 (1987), 341-354.

8 See chapter two of the M A (Biblical Studies) dissertation of the author for a detailed exegesis of the Psalm.

9 W S Prinsloo, "Psalm LXXXII: Once again, Gods or men", unpublished paper read at the IOSOT conference in Paris, (July 1992) 1-9.

10 Morris, ibid, 208.

11 H Kvalbein, "Jesus and the poor: two texts and a tentative interpretation", Themelios 13 (1987), 80-87. See also H J Kraus, Theology of the Psalms, Augsburg 1986, 153.

$12 \mathrm{~J}$ McPolin, "Psalms as prayers of the poor", in: Back to the sources. Biblical and Near Eastern Studies in honour of Demot Ryan, (Edited by K J Cathcart \& J F Henley), Glendale 1989, 94.

13 R W Lyon, "Abandoning power. The L.O. Society at Asburg Theological Seminary", Transformation 3/4 (1986), 10-14.

14 S C Mott, "A response to: 'Abandoning power'", Transformation 3/4 (1986), 15-16.

15 Mott, ibid, 12.

16 J Moltmann, The power of the powerless, London 1983.

17 Moltmann, ibid, ix.

18 D L Miglore, The power of God, Philadelphia 1983.

19 Miglor, ibid, 17.

20 Miglor, ibid, 19.

21 C Shourie, "Poverty is powerlessness", Evangelical Review of Theology 11 (1987), 254-260. 
22 Shourie, ibid, 255.

23 Shourie, ibid, 255.

24 Shourie, ibid, 258.

25 Shourie, ibid, 256.

26 Shourie, ibid, 256.

27 Shourie, ibid, 258.

28 Shourie, ibid, 257, 258, 259.

29 Shourie, ibid, 259.

$30 \quad$ Shourie, ibid, 257.

31 Shourie, ibid, 257.

32 H R Weber, "Power: some biblical perspectives", The Ecumenical Review 38 (1986), 265-279.

33 Mott, ibid, 15-16.

34 Gowan, ibid, 341-353.

35 Gowan, ibid, 347.

36 Gowan, ibid, 349.

37 M Carmichael, \& J Hamilton, Black power, New York 1967, 35.

38 Carmichael \& Hamilton, ibid, 46.

39 R de Vaux, Ancient Israel: its life and institutions, London 1973, 72-74.

40 Shourie, ibid, 254-255. 